\title{
Towards Developing a Theoretical Framework on Career Success of
}

\section{People with Disabilities}

\author{
Nor Wahiza Abdul Wahat \\ Department of Professional Development and Continuing Education \\ Faculty of Educational Studies, Universiti Putra Malaysia \\ 43400, Serdang, Selangor, Malaysia \\ Tel: 60-1-2207-8054Ｅ-mail: norwahiza@gmail.com
}

\begin{abstract}
Malaysian workforce is increasingly encompassed by a group of minority who are incapacitated due to some illness or perhaps an accident. They are known as the people with disabilities (PWDs). More attention and initiatives are now built for the PWDs, thus leading to the assumption that they should be enjoying better level of career success. Thus, the purpose of this paper is to develop a theoretical framework for measuring PWD's career success based on the integration of sponsored mobility model of career success and person environment perspective. Suggested predictive potential of four key factors on PWD's career success are person-job fit perception, needs-supplies fit perception, core self-evaluation and universal work environment. The developed theoretical framework would lead to an empirical study on objective and subjective career success of PWDs in Malaysia. The framework suggests specific individual attribute, personality and perception can lead to better objective and subjective career success. PWDs having positive core self-evaluation, higher levels of person-job fit and needs-supplies fit perception are believed to achieved better career outcomes, that is objective and subjective career success.
\end{abstract}

Keywords: People with disabilities, Career success, Theoretical framework

\section{Introduction}

The labor force in Malaysia is encompassed by various groups of people, including the minority who are incapacítate due to certain illness or accident. They are the so called people with disabilities (PWDs). As with other minority groups, the PWDs are often associated with marginalized treatment and opportunities. For example, in year 2003, a total of only 5.24\% of PWDs are reported to be employed in Malaysia (Serajul Haq, 2003). It has also been reported that until March 2007, a total of 6,799 out of 9,070 registered PWDs were employed (Rosmawati Sulaiman, 2008).

In Malaysia, The Disability Act 2007 was established to address the rights of PWDs. Even though Malaysia could be regarded as laid back in comparison to developed countries such as the United Kingdom, which has established its Disabled Persons (employment) Act since 1944, the newly established Act marked a growing acknolwedgement of PWDs as important component of the Malaysian workforce. Following the establishment of policy stating that one percent of Malaysia workforce would be made up of PWDs, more initiatives were taken by various parties including the Human Resource Ministry, the Women, Family and Community Development Ministry and the Department of Social Welfare, the Malaysian Council for Rehabilitation (MCR), Malaysia Confederation of Disabled (MCD) and other non-governmental agencies to steer the policy objectives. These include the government's effort to mobilize an allocated amount of RM22 million in the 9th Malaysian Plan for PWDs involvement in enterpreneurship. The allocation was channelled through the Enterpreneurship Programme for People with Disabilities Scheme (SBGP-OKU) which was already introduced in 2006. Given such scenario, assumptions could be made that this minority workforce would be enjoying better career success compared to the times when they were getting lesser attention and assistance. Despite such governmental effort, forty four PWDs have been reported to join the scheme in 2007. Could it be that the heterogeneity among the PWDs due to types of disabilities (physical, sensory, intellectual, psychiatric, multiple disabilities, permanent, temporary, episodic and perceived disabilities) or educational background (special, mainstream or combined type of education) be the underlying reason for the inconsistency among the PWDs to benefit from available opportunities? Perhaps, there are some contribution of internal or external factors that could help to explain why such phenomenon is happening. 
Hence, there is a calling to uncover the reality by looking into possible predictors of PWDs' career success based on an integrated theoretical framework.

The paper shall begin by reviewing how the shift of focus in defining career concept (Super, Tiedman and Borrow,1961; McDaniels, 1965; Jordaan, 1974; (Melamed, 1996; Whitely, Dougherty and Dreher, 1994), later led to the emergence of subjective component in career success (Judge et al. 1995; Seibert et al., 2001; Heslin, 2003; $\mathrm{Ng}$ et al., 2005; Breland et al., 2007). The theoretical framework developed from integration of person-environment perspective and sponsorship mobility of career success model that proposes the role of four key predictors, namely person-job fit perception, needs-supplies fit perception, core self-evaluation and physical work environment in people with disability's career success is then discussed. These proposed key predictors serve as the basis for hypothesis on people with disability's career success. The paper also provides a review of researches that investigated the associations between the predictors and people with disabilities' career success. This review is based on an extensive search of relevant studies published all over the world, including those conducted in Malaysia.

\section{Definition of Career Success}

In the early $20^{\text {th }}$ century, career has been referred to synonymously as occupation. In the 1950 s and 1960 s, career was viewed by relating occupation to individual's life. Super, Tiedman and Borrow (1961) defined career as the sequence of occupations, jobs and the positions in life of an individual. Leisure was later on suggested by McDaniels (1965) integrated to career definition to give it a broader perspective. Moving on to the 1970s and 1980s, the concept of career was continuously defined in a broader perspective. For instance, the National Vocational Guidance Association (NVGA) in 1973 defined career as a 'time-extended working out of a purposeful life pattern through work undertaken by the individual'. Career started to be viewed in a broader sense that incorporates almost all life activities, across individual's lifespan, and no longer occupational in manner. Thus, in the 1970s, developmental approach of career started to take place featuring the shift from occupational criteria to career criteria (Jordaan, 1974).

The evolution of career theory has thus posed a similar effect on the definitions of career success. When the construct of career success was introduced in the year 1937 by Hughes and the Chicago School of Sociology during the 1930s, early psychological career development theories focused on more active role of organizations in determining individual's career success. Career success was defined rather objectively by focusing on the more visible aspects of an individual's career circumstances, such as profession, work role, salary, type of work, career progression, and status or prestige associated with a position or level on a hierarchy (Van Maanen, 1977). It is being measured in terms of society's evaluation of achievement with reference to extrinsic measures such as salary, managerial level and number of promotions (Melamed, 1996; Whitely, Dougherty and Dreher, 1994).

Later, along with the development of career theories especially from the beginning of the 1970s, the definition of career success began to incorporate the aspect of subjectivity. Subjective career success describes a personal interpretation of one's career and no longer includes the reflection of social norms towards one's career (Heslin, 2005). According to Judge et al. (1995), Seibert et al. (2001), Heslin (2003), Ng et al. (2005) and Breland et al. (2007), career success is described as the positive psychological or work-related outcomes or personal and professional achievements one has gathered from their working experience. Similarly, career success was defined by Arthur et al. (2005) as "an outcome of a person's career experiences ... the accomplishment of desirable work-related outcomes at any point in a person's work experiences over time". Subjective career success can be measured in terms of individual's feelings of success with reference to intrinsic indices such as perceptions of career accomplishments and future prospects (Aryee et al., 1994). It is now believed that an individual who is objectively successful by getting a very high pay, got promoted or empowered with supervision authority, may still be unhappy. This is due to the fact that individual's perspective on success is actually affected by life situations such as family commitments, dual income and health (Gunz and Heslin, 2005).

As new definitions of career success incorporated both objective and subjective elements of career success, more studies have examined both interdependently (Arthur et al., 2005; Hall \& Chandler, 2005). Besides, solely trying to explain objective career success or social career success, arising importance of subjective career success as a psychological career success inclusive of hopes and desires, values and beliefs that imply individuals' psychological well-being and quality of working life was highlighted (Peluchette, 1993; Nabi, 2003). Hand in hand, both are said to contribute to holistic individual growth at work (Ashforth, 2001; Hall, 2002; Hall \& Chandler, 2005). Though literatures pointed out the predictive influence of objective success on subjective career success, more studies significantly found disassociation between the two. Such ongoing debate spelled the importance for further studies of career success. Thus more studies on career success including the ones within the 
context of disabled people would help to enrich the findings on interaction between objective and subjective career success.

Further understanding of career success based on traditional, new and contemporary career theories for both individual and organizations is illustrated in Table 1.

In the context of PWDs' career success, Lysaght et al. (1994) argued that linear career progression characterized by full-time continuous working would not at all explain the total meaning of their career success. In contrast to the traditional meaning of career success, the PWD's career success might be more achievable with the element of flexibility, such as flexible working hours and locality. However, special treatments to the PWDs would only mark their disabilities. As stated by Sutherland (1981), the more one's career patterns conform to the societal norms, the lesser one's disability is apparent to the society. Taking note of this, career success would then depend on the subjective meaning provided by PWDs themselves. Sonali Shah (2005) in her study on career success of disabled high-flyers, identified the essence of both internal and external career success for the PWDs. It was found that career success was not just defined conventionally by looking at hierarchical progression in career and salary by 31 disabled adults. Most are holding highly recognized positions in their organizations and society, as well define their career success by referring to internal criteria such as feelings of personal satisfaction or happiness with oneself, one's work, one's life; feelings of personal development, and equality. The subjectivity in defining career success is due to the physical and structural barriers faced by the PWDs imposed by mainstream society. Thus in this section, the author would like to propose the importance of looking at both PWDs' objective and subjective career success interdependently. The PWDs have been acknowledged the minority workforces whom are still in the struggle to position themselves significantly in the mainstream society. At the same time, it would definitely be a negligence to ignore the subjective aspect of career success since it would very much explain the psychological component, inclusive of the feelings and perceptions of the PWDs on their life-career success. Having this, it is proposed that career success of the PWDs should be measured both objectively and subjectively in order to understand the phenomenon better.

\section{Person-Environment Perspective and Sponsorship Mobility of Career Success Model}

The person-environment perspective and sponsorship mobility of career success model is applied to explain the phenomenon of PWDs' career success. The person-environment perspective emphasizes on positive, significant individual and organizational outcomes due to harmonious interactions between the two (Schneider et al.2000). This perspective was first introduced by Parsons (1909). Chatman's (1989) Behavioural Interaction Theory and Lewin's (1939) view that individual's behavior resulted from individual-organization interaction were nested in the perspective. In other words, the perspective proposes that it is not sufficient to explain individual's work behavior by focusing on either individual' characteristics or work situation alone. Rather, a comprehensive understanding would be possible by looking at the interactions between the two parties. The concept of person-environment fit (PE fit) could be claimed as an all-encompassing concept in the field of psychology as it has been studied in relation to personality theory, vocational psychology, personnel selection, social psychology and various aspects of work behaviour as well as environment. This is clearly illustrated in Table 2.

Complementary fit is one of the main dimensions in the person-environment perspective. It occurs when the individual's characteristics complements what is yet to be completed in a work environment to ensure satisfaction and satisfactoriness. Under the umbrella of this dimension, lies two types of fitness, which are the needs-supplies and person-job fitness. The needs-supplies fitness refers to environmental role in providing financial, physical, psychological, developmental and other types of sources needed by individuals in their work place. Such fitness would result in individual's satisfaction (Kristoff, 1996). Meanwhile, the person-job fitness describes the work environment's requirement towards individual's time, energy, commitment, knowledge, skills and abilities (Wilk \& Sackett, 1996). The fitness is achieved when the individual is able to perform what the job or work environment demands. It has been reported that harmonious adjustments between an individual and his or her work place lead to positive outcomes such as job satisfaction, commitment, low turnover intention (Sekiguchi, 2004).

The sponsored-mobility model of career success elaborates on the role of organizational sponsorship in helping certain individuals to excell in their career. Access to activities and certain benefits help the individuals to perform better and thus achieve better career outcomes. The internal labor market theory (Spilerman, 1977) which posits that organization's investments in their employees lead to outstanding employees nested in this perspective. The investments could be in various forms such as training and development opportunities, supervisory support and multiforms of organizational resources. Previous literatures proposed that minority groups were less likely to be chosen for such investments in order to achieve better career success because they are regarded as less worthy (Kanter, 1977; Greenhouse, Parasuraman \& Wormly, 1990). Hence, in developing the theoretical framework for 
career success of the PWDs, the author proposed to look into the conduciveness of physical workplace environment for the PWDs as a way to explain the career success of the PWDs. By integrating the person-environment fit perspective and sponsorship model of career success, the author identified three sets of factors that could be tested as predictors of PWDs' career success. These factors are:

(1) individual characteristics;

(2) person-environment fit factors; and

(3) organizational factor

Traditionally, individual characteristics (eg. education, age and gender), person-environment factors (eg. person-job fit and needs-supplies fit perceptions) and organizational factors (eg. work environment) have been used to examine the career success of employees in various contexts (Sonali Shah, 2005; Ballout, 2007; Morley, 2007; Judge 2009).

The following section elaborates on the effects of the four key factors on PWDs' career success.

\section{Predictor's of PWDs' Career Success}

In the previous section, the author have concluded that the predictors of the PWDs' career success can be categorized into three main categories (i.e individual-related factors, person-environment fit and organizational factors). In this section, we discuss the effects of each of these factors on PWDs' career success and provide empirical evidence relating to the factors. Finally, we offer formulated hypotheses on each of the key factors.

\subsection{Individual-related factors}

The person-environment perspective and sponsorship model of career success which serves as the theoretical framework theorize the joint influences of person-related factors with other factors on career success. Among the person-related factors or individual attributes associated with career success are gender, age and education. Nabi (1999) in his study on the relationship between age, gender, education, and ambition with objective career success found significant relationship between all the individual attributes with objective career success. In the context of PWDs, Hendey and Pascall (2001) postulated the disabling effect of special education. The special education limits choices, discriminates and disables individuals from experiencing wider range of training and employment opportunities. The segregated experience also deny them from the exposure of realities and thus do not prepared them well to deal with the mainstream society (Barnes, 1991; Shakespeare \& Watson, 1998). Thus, combined special and mainstream education is proposed to produce better career success for the PWDs (Sonali Shah, Travers \& Arnold, 2004). As boys were expected to be more courageous, self-supporting, task-involved and confident than girls, it is natural that disabled men are also expected to perform better at work compared to disabled women. Having to deal with such challenging stereotypes, disabled women were found to be more dedicated to their work (as a given opportunity), compared to disabled men (Bauman, 1997).However, most often, women with disabilities were lowly employed (Scott, 1993) as they were being stereotyped as helpess to perform any kind of work (Gill, 1997). Earlier, age and education were also empirically proven to be significant to career success of those with disabilities (Lewis \& Allee, 1992).

Core self-evaluations (CSE) has also been reported to influence career success. Core self-evaluation (CSE) as an appraisal of one's self-worth is found to predict high level of job and life satisfaction (Judge, 2009). It is broader than self-esteem because it also reflects beliefs in one's capabilities (to control one's life) and one's competence (to perform, cope, persevere, and succeed). It also covers the general sense that life will turn out well for oneself. CSE is indicated by four traits, which includes self-esteem, generalized self-efficacy, locus of control and neuroticism. Thus, based on this arguments, we predict that:

H1: Individual-related factors (age, gender, education and core self-evaluation) have significant positive relationship with PWDs' objective and subjective career success.

\subsection{Person-Environment Fit Factors}

As the individual-related factors emphasize individual attributes, the person-environment factos highlight the role of person-job fit perception and needs-supplies fit perception in determining career success of the PWDs. The person-environment perspective posits that harmonious interactions between individuals and the environment (eg.work place) would lead to better work and career outcomes. Person-job fit perception and needs-supplies fit perception are among the person-environment variables that have been proven to have relationships with career success in past studies. The results of recent studies by Ballout (2007) and Morley (2007) suggested person-job fit and needs-supplies fit perceptions as important antecedents of career success. In other words, individuals with high levels of person-job and needs-supplies fit perceptions are predicted to have high levels of career success, and vice 
versa. Pertaining to the very marginal number of successful PWDs in Malaysia, there is a concern of PWDs compliance to societal attitudes and misconception on their inabilities to perform well at workplaces. The compliance to the misfit perception may lead them to set career goals far from what they could actually achieved. It is intriguing to look at how the employed PWDs themselves perceive the compatibility of their knowledge, skills and abilities (KSAs) to the job and task demands. The role of PWDs' person-job fit perception and needs-supplies fit perception on their objective and subjective career success in this context are yet to be determined. Thus, the author would like to propose the following hypothesis:

H2: Person-environment factors (person-job fit perception, needs-supplies fit perception and core self-evaluation) have significant positive relationship with PWDs' objective and subjective career success.

\subsection{Organizational factor}

The sponsored-mobility model of career success emphasizes the role of organizational sponsorship to ensure individuals career succes. Access to activities and certain benefits help the individuals to perform better and thus achieve better career outcomes. The internal labor market theory (Spilerman, 1977) which posits that organization's investments in their employees lead to outstanding employees nested in this perspective. The investments could also include accessible physical work environment and accessibility to the work place. The PWDs are likely to be chosen for such investments and achieve better career success if they are regarded as worthy. The manifestations of good inclusive design actually conveys the message of 'you are important' to the PWDs. However, past studies have indicated that PWDs are impaired not only internally but also externally. This happen when they failed to be employed simply because of non-accommodating architectural environment of the work places. Such type of impairment is known as external impairment and work place disabilities (Bernell, 2003).

Imric (1996) argued that apartheid designed environment, prioritizes the 'able-bodied' community and locked the PWDs out. Examples are designs with use of steps with no ramp and lift buttons that are designed too high and unreachable for those on wheel chairs. Observations showed that most of the premises in Malaysia are not yet built in universal designs that is accesible for all groups of people, including the PWDs. Physical barriers remain as major constraints for employed PWDs to be more productive in their work. This situation perpertuates that besides dealing with PWD issues based on the contemporary societal model, there is still a need to tackle society's awareness on physical disabilities, which emphasized the more classical biological model. The model has defined disabled people with reference to biological properties. Improved organizational structures, facilities and opportunities are very much needed to increase the PWDs' accessibility, productivity and career development. Based on the discussion above, the following hypothesis is proposed:

H3: Organizational factor (physical work environment) has significant positive relationship with the PWDs' objective and subjective career success.

\section{Conclusions and Implications for HRD theory and practice}

This article has aimed to develop a theoretical framework for measuring PWDs' career success (both objective and subjective). The integration of person-environment fit perspective and sponsorship model of career success underlies the developed theoretical framework. The article concludes that the three key factors (i.e individual, person-environment fit and organizational factors) could potentially predict objective and subjective career success of the PWDs (see Figure 1). The central tenet of all key factors is the harmonious interaction between individual and organizational factors, with emphasis on individual development and performance. The domains of person-environment interactions are in line with the three core areas of HRD, as diversity (which in this case is disability) is now being increasingly recognized and addressed in the implementation of HRD practices: (1) personnel training and development; (2) career development and; (c) organizational development. A shift to the present knowledge-based economy, which is moved by brainpower calls for inclusion of all potential individuals to contribute and participate in the workforce. As a matter of fact, a senior economist with Human Resources and Skills Development Canada, Kamal Dib (2004) believed that strategic HRD practices that involve inclusion principles that do not waste any potential human resources because of their differences would lead to more innovativeness and performance within organizations.

The present framework suggests specific individual attribute, personality and perception can lead to better objective and subjective career success. PWDs having positive core self-evaluation, higher levels of person-job fit and needs-supplies fit perception are believed to achieved better career outcomes, that is objective and subjective career success. Hence, specific programs for personnel training and development for the PWDs such as confidence stimulation and job-related knowledge and skills training should be provided by the organizations. Career development assistance programs including counseling should also be provided in organizations which employed the PWDs. Nevertheless, having positive self-evaluation, right set of mind and perception is not 
sufficient. Organizations also play important role through organizational development interventions such as supervision and coaching to guide the PWDs in their career planning and throughout their career path. Feedbacks from the supervisors and superiors on their performance would allow the PWDS to be constantly aware of their performance and thus avoid the formation of low person-job fit perception. On top of all the training, developmental and career assistance programs for the PWDs, support from the senior management in the efforts to empower the PWDs is very important. The support can be in many forms, including their involvement as trainers in programs which targeted to increase employees' awareness, knowledge, skills and behaviors on diversity in organizations. Better understanding of organizational members on how to deal with diversity within organization, such as the PWDs may lead to better treatment and provision of more opportunities that could enhance the PWDs' person-job fit perception, needs-supplies fit perception and core self-evaluation. We further conclude that organizations should take into account the provision of accessible physical work place environment for the PWDs. There is a need to shift the current disabling physical environment which is based on needs of mainstream society to more universally designed, accessible environment. More accessibility would lead to more opportunity of realizing the PWDs' potentials which could results in better productivity of organizations.

\section{References}

Arthur, M. B., Khapova, S. N., \& Wilderom, C. P. M. (2005). Career success in a boundaryless career world. Journal of Organizational Behavior, 26: 177-202.

Aryee, S., Chay, Y. W., \& Tan, H. H. (1994). An examination of the antecedents of subjective career success among a managerial sample in Singapore. Human Relations, 47, 487-509.

Ashforth, B. E. (2001). Role transitions in organizational life: An identity-based perspective. Hillsdale, NJ: Erlbaum.

Ballout, H.I. (2007). Career success: the effects of human capital, person-environment fit and organizational support. Journal of Managerial Psychology, 22 (8): 741-765.

Baruch, Y. (2004). Managing Careers: Theory and Practice. Pearson Education Limited: Glasgow.

Bernell, S. L. (2003). Theoretical and applied issues in defining disability in labor market research. Journal of Disability Policy Studies, 14(1):36-45.

Breland, J. W., Treadway, D. C., Duke, A. B. and Adams, G. L. (2007). The interactive effect of leader-member exchange and political skill on subjective career success. Journal of Leadership and Organizational Studies, 13(3): $1-14$.

Brewer, J.M. (1922). The vocational guidance movement. New York: Macmillan.

Chatman, J. (1989). Improving interactional organizational research: a model of person-organization fit. Academy of Management Review, 14: 333-49.

Dawis, R.V., \& Lofquist, L.H. (1984). A psychological theory of work adjustment. Minneapolis. MN: University of Minnesota Press.

Derr, C.B. (1986). Managing the new careerists. San Francisco:Jossey-Bass.

Dib, K. (2004). Diversity works. Canadian Business, 77(7): 53-54.

Greenhaus, J. H., Parasuraman, S., \& Wormley, W. M. (1990). Effects of race on organizational experiences, job performance evaluations, and career outcomes. Academy of Management Journal, 33: 64-86.

Gunz, H. P., \& Heslin, P.A. (2005). Reconceptualizing career success. Journal of Organizational Behavior, 26, $105-111$.

Hall, D. T. (2002). Careers in and out of organizations. Thousand Oaks, CA: Sage.4ughc4ughcy3t6z54.

Hall, D. T., \& Chandler, D. E. (2005). Psychological success: When the career is a calling: Journal of Organizational Behavior, 26: 155-176.

Hendey, N. \& Pascall, G. (2001). Disability and Transition to Adulthood: Achieving Independent Living. London: Pavilion Publishing.

Heslin, P. A. (2003). Self- and other-referent criteria of career success. Journal of Career Assessment, 11: 262-286.

Heslin, P. A. (2005). Conceptualizing and evaluating career success. Journal of Organizational Behavior, 26 : $113-136$. 
Holland, J. L. (1997). Making vocational choices: A theory of vocational personalities and work environments (3rd ed.). Englewood Cliffs, NJ: Prentice-Hall.

Imrie, R. (1996). Disability and the city: international perspectives. London: Paul Chapman Publishing.

Jordaan, J. P. (1977). Career development theory. International Review of Applied Psychology, 26: 107-114.

Judge, T. A., Cable, D. M., Boudreau, J. W., \& Bretz, R. D. (1995). An empirical investigation of the predictors of executive career success. Personnel Psychology, 48: 485-519.

Judge, T.A. (2009). Core self-evaluations and work success. Current Directions in Psychological Science, 18(1):58-62.

Kanter, R. M. (1977). Men and women of the corporation. New York: Basic Books.

Kristof, A. (1996). Person-organization fit: an integrative review of its conceptualizations, measurement and implications. Personnel Psychology, 49 (1):1-49.

Lewin, K. (1951). Field theory in social science: Selected theoretical papers. New York: Harper.

Lysaght, R., Townsend, E., \& Orser, C.L. (1994). The use of work schedule modification to enhance employment outcomes for persons with severe disability. Disability and Society, 11(2): 235-248.

McDaniels, C. (1965). Vocation: A religious search for meaning. Vocational Guidance Quarterly, 14, 31-35.

Melamed, T. (1995). Career success: The moderating effect of gender. Journal of Vocational Behavior, 47, 35-60.

Morley, M. (2007). Person-organization fit. Journal of Managerial Psychology, 22(2): 109-117.

Murray, H.A. (1938). Exploration in personality. New York:Oxford University Press.

Nabi, G. (1999). An investigation into the differential profile of predictors of objective and subjective career success. Career Development International, 4(4):212 - 224.

Nabi, G. R. (2003). Situational characteristics and subjective career success: The mediating role of career-enhancing strategies. International Journal of Manpohwer, 24 (6): 653-671.

Ng, T. W. H., Eby, L. T., Sorensen, K. L., \& Feldman, D. C. (2005). Predictors of objective and subjective career success: a meta-analysis. Personnel Psychology, 58: 367-408.

Parsons, F. (1909). Choosing a vocation. Boston: M.A. Houghton Mifflin.

Peluchette, J. (1993). Subjective career success: The influence of individual difference, family, and organizational variables, Journal of Vocational Behavior, 43:198-208.

Rosmawati Sulaiman. (2008). Faktor-faktor pendorong golongan kurang upaya (OKU) bekerja di Jaro (Johor Area Rehabilitation Organization). [Online] Avasilable: www.fp.utm.my/...pdffail/...Rosmawati BP050157D2008TTP.pdf.

S, Shah. (2005). Career success of disabled high-flyers. London: Jessica-Kingsley Publishers.

Schneider, B. (1987). The people make the place. Personnel Psychology, 40: 437-453.

Schneider, B., Smith, D.B., Taylor, S. \& Fleenor, J. (2000). Attraction-selection-attrition: Toward a person-environment psychology of organizations. In W. B.Walsh K.H, Craik, \& R.H., Price. (Eds.), Person-environment psychology: New directions and perspectives (pp.61-85). Mahwah. N.J: LEA Publishers.

Seibert, S. E., Kraimer, M. L., \& Crant, J. M. (2001). Why do proactive people do? A longitudinal model linking proactive personality and career success. Personnel Psychology, 54(4):845-874.

Sekiguchi, T. (2004). Toward a dynamic perspective of person-environment fit. Osaka Keidai Ronshu, 55(1):177-190.

Serajul Haq, F. (2003). Career and employment opportunities for women with disabilities in Malaysia. Asia Pacific Disability Rehabilitation Journal, 14(1): 71-78.

Spilerman, S. (1977). Careers, labor market structure, and socioeconomic achievement. American Journal of Sociology, 83:551-593.

Super. D.E., Tiedeman, D.V. \& Borow, H. (1961). Vocational development: A symposium, personal and Guidance Journal. Personnel and Guidance Journal, 40(1):11-25.

Sutherland, A. (1981). Disabled we stand. London: Souvenir Press. 
Van Maanen, J. (1977). Experiencing organization: Notes on the meaning of careers and socialization. In J. Van Maanen (Ed.), Organizational careers: Some new perspectives (pp. 35-50). New York: Scribner.

Whitely, W., T.M. Doughterty \& G.F. Dreher. (1991). Relationship of career mentoring and socioeconomic origins to managers' and professionals' early career progress. Academy of Management Journal, 34:331-351.

Wilk, S. \& Sackett, P. R. (1996). A longitudinal analysis of ability-job complexity fit and job change. Personnel Psychology, 47: 937-96.

Table 1. Career Concepts Related to Career Success

\begin{tabular}{|c|c|c|}
\hline $\begin{array}{l}\text { Traditional } \\
\text { concepts }\end{array}$ & $\begin{array}{l}\text { The New Careerist } \\
\text { (Derr, 1986) }\end{array}$ & Contemporary individual \\
\hline Formal education & Getting ahead & Self development, competencies \\
\hline $\begin{array}{l}\text { Lifelong employment, job } \\
\text { security }\end{array}$ & Getting secure & Employability \\
\hline \multirow{4}{*}{$\begin{array}{l}\text { Up the ladder, salary } \\
\text { progression }\end{array}$} & Getting high & Lateral transitions, spiral movement \\
\hline & $\begin{array}{l}\text { Getting free } \\
\text { Getting balanced }\end{array}$ & $\begin{array}{l}\text { Self management, entrepreneurship } \\
\text { Quality of life } \\
\text { Work family balance }\end{array}$ \\
\hline & & $\begin{array}{l}\text { New psychological contracts, search for } \\
\text { spiritual meaning based on individual } \\
\text { consciousness, leisure activities, health } \\
\text { consciousness }\end{array}$ \\
\hline & & Career resilience \\
\hline
\end{tabular}

Source: Adapted from Baruch (2004, p. 77) 
Table 2. Theories in Interaction with Person-Environment Fit Concept

\begin{tabular}{|l|l|l|}
\hline Theory & Scholar & \multicolumn{1}{|c|}{ Basic Propositions } \\
\hline Interaction Theory & Lewin (1951) & $\begin{array}{l}\text { Individual's behavior is determined } \\
\text { by the interaction between the } \\
\text { individual and the environment }\end{array}$ \\
\hline Need-Press Theory & Murray (1938) & $\begin{array}{l}\text { Environmental presses aid or block } \\
\text { individuals from meeting their } \\
\text { physical and psychological needs }\end{array}$ \\
\hline Theory of Work Adjustment & $\begin{array}{l}\text { Dawis and Loftquist } \\
(1984)\end{array}$ & $\begin{array}{l}\text { Successful work relations resulted } \\
\text { from adjustments intended to create } \\
\text { a state of correspondence between } \\
\text { individual and environment } \\
\text { characteristics }\end{array}$ \\
\hline $\begin{array}{l}\text { Attraction-Selection-Attrition } \\
\text { Theory }\end{array}$ & Schneider (1987) & $\begin{array}{l}\text { Individuals in organizations are } \\
\text { attracted to, chosen by and chose to } \\
\text { remain within an organization }\end{array}$ \\
\hline $\begin{array}{l}\text { Theory of Vocational } \\
\text { Behavior }\end{array}$ & Holland (1997) & $\begin{array}{l}\text { Individual's vocational satisfaction, } \\
\text { stability and achievement are } \\
\text { determined by congruences between } \\
\text { individual's interest and his/her } \\
\text { environment }\end{array}$ \\
\hline
\end{tabular}

\begin{tabular}{|l|}
\hline Individual-Related Factors \\
Gender \\
Education \\
Age \\
Core-self evaluation \\
\hline
\end{tabular}

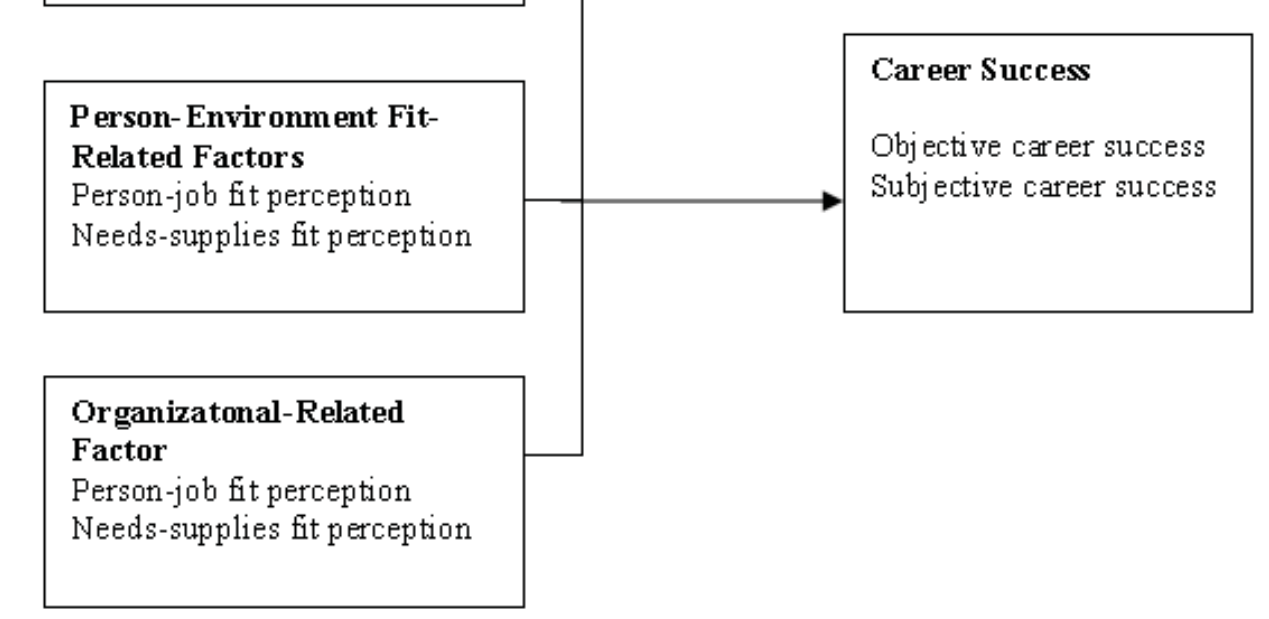

Figure 1. Theoretical framework for measuring PWDs' career success 